\title{
Scaling up Innovative Teaching Approaches in Mathematics: Supporting Teachers to Take up a New Role as Professional Development Course Leaders for Inquiry-Based Learning
}

\author{
Katja Maßß \\ Correspondence: Katja Maß, International Centre for STEM education, University of education Freiburg, Germany.
}

Received: March 12, 2018

doi:10.11114/jets.v6i7.3261

\author{
Accepted: May 2, $2018 \quad$ Online Published: May 7, 2018 \\ URL: https://doi.org/10.11114/jets.v6i7.3261
}

\begin{abstract}
This paper reports on a professional development activity (PD) for course leaders, which was designed within the European project Primas (2010-13, www.primas-project.eu). Primas aimed at the implementation of inquiry-based learning (IBL) in day-to-day teaching on a large scale. The focus is on the education of mathematics course leaders in Germany, who were all teachers. In order to support them in taking up their role and run courses on (IBL), a course leader seminar following design research was developed. The course aimed at course leaders' learning on two levels: (1) as mathematics teachers about IBL and (2) as course leaders about running PD on IBL. A small scale retrospective interview study gives insights into the needs the participants face when learning about IBL as teachers and when learning as future course leaders. It also illuminates in which way participants took up their role as a course leader. These insights suggest how to optimize the course following design research.
\end{abstract}

Keywords: course leader professional development, professional development, inquiry-based learning, interview study

\section{Introduction}

In 2007, the Rocard-Report initiated by the European Commission and written by a group of educational experts (Rocard \& al. 2007) recommended inquiry-based learning (IBL) as opposed to transmission-based learning for mathematics and science education, so as to raise students interest for these subjects and their competences in them (here, we focus on mathematics). However, it is not easy for teachers to change their way of teaching from transmission-based teaching to inquiry-based teaching as it requires a change of their role in class from a transmitter of knowledge to a moderator of learning processes (Swan 2005, 2007) as a closer look at these teaching approaches reveals.

In transmission-based mathematics classes, the teacher points out what must be observed, provides the questions, demonstrates the methods to be used, checks results, and so on while students are left only to employ well-rehearsed procedural techniques (Mullis, Martin \& Foy 2008; Stigler, Gonzales, Kawanaka, Knoll \& Serrano 1999).

In IBL lessons, students are invited to observe phenomena and create their own questions, select mathematical approaches; carry out hands-on experiments, create representations to clarify relationships, seek explanations, interpret and evaluate solutions, and communicate their solutions (Dorier \& Maass, 2014).

Thus, following on from the Rocard-Report, the European Commission funded several research projects aiming at a large-scale implementation of IBL. The explorative study presented here, was carried out within the project Primas. Primas was one of the first projects which received funding within the initiative "Science in Society" in the 7 th framework programme. In Primas, between 2010 and 2013, 14 universities from 12 countries (Cyprus, Denmark, England, Germany, Hungary, Malta, Netherlands, Norway, Romania, Slovakia, Spain, Switzerland) collaborated to promote the implementation of IBL in mathematics and science (see www.primas-project.eu).

In Primas we intended to support teachers with the implementation of IBL by professional development (PD) courses, one of the main means of providing teachers' professional development. Because we aimed at a widespread implementation of IBL, the question of how to support large numbers of teachers with high-quality PD was relevant (Maass \& Artigue 2013). In the literature, several approaches to scaling up PD are discussed, amongst which is the Cascade model, in which course leaders are educated in the first step of the cascade, and then in turn run their own PD courses (ibid.) (in the second step of the cascade). The cascade model was selected because it was widely used in 
several partner countries, and therefore seemed to be appropriate to reach the required number of teachers (more than 100 teachers per country).

Unfortunately, research on scaling up professional development has only just begun (Loucks-Horsley 2010) and little is as yet known about how to educate mathematics course leaders (Rösken-Winter, Schüler, Stahnke \& Blömeke 2015). This holds in particular to IBL. Naturally, the answer to this question also relates to course leaders' professional backgrounds, which can be a university degree with a theoretical background in mathematics education, a school authority (Jackson et al. 2015), or a mathematics teacher still teaching at school (Krainer 2015).

In this paper I report on a PD course for course leaders (from now on called a course leader seminar so as to distinguish it from the teachers' PD activities), which was designed within Primas for the education of 20 mathematics course leaders in Germany. This course leader seminar was of significance for Germany as the cascade model is a model commonly used in Germany, but is not research-backed. The course leaders in the German seminar were all mathematics teachers and consequently had to face particular challenges. First of all, at the beginning of Primas, IBL was by no means widespread and so the teachers willing to be educated as course leaders had no experience with IBL themselves and thus had to learn how to teach in an inquiry-based way. Second, they had almost no experience in running PD courses and therefore had to learn to do so. Third, this course leader seminar was particularly challenging for them as they had to try out new teaching approaches on top of their normal workload and additionally had to learn how to run PD courses for other teachers. Altogether, we thus cannot underestimate the challenges regarding time demands and new competencies that these future course leaders had to resolve.

In order to support the German course leaders in taking up their role and run IBL related courses, the German team developed a course leader seminar following design research. The seminar was long term, comprising ten seminar days spread over more than two years with practice phases in between. It aimed at course leaders' learning on two levels: (1) as mathematics teachers about IBL; and (2) as course leaders, about running PD on IBL.

The aim of the explorative study presented here was to discover to what extent the carefully designed seminar met the needs of the course leaders and to optimize the course accordingly. The research questions were:

1) What needs did participants express as teachers learning to use IBL?

2) What needs did participants have in relation to their preparation as course leaders?

3) How did participants perceive their role as a course leader?

4) To what extent were the course leaders' and the teachers' roles intertwined?

The first two questions relate to the demand of starting off from participants needs in such a course (Gusky 2000); the third and fourth question specifically relate to the double role participants had to take.

\section{Theoretical Background and Implementation}

In the following, I will first discuss IBL so as to outline the specific challenges it poses for mathematics teachers. Then I will turn to professional development of teachers and course leaders and the implementation in Primas.

\subsection{Inquiry-Based Learning and Its Implementation in Class}

As described above, IBL refers to a more student-centred way of teaching in which students explore phenomena and find their own path to solutions. However, definitions of IBL vary. Amongst others they vary in relation to the degree of autonomy given to students in the inquiry process (Artigue \& Blomhøj 2013). Primas followed a socio-cultural approach to IBL in which learning needs to happen in interactive, social, classroom settings. Here, the teacher supports students in an active but non-directive way (Radford 2010). Research evidence appears to show that this approach is more effective than more teacher-centred approaches (Swan 2006; Hmelo-Silver, Duncan \& Chinn 2006). For more information on the effects of IBL on students we refer to Bruder and Prescott (2013).

Due to different understandings of IBL in the theoretical discussion and different perspectives in the countries involved in Primas, it seemed important to develop a common definition of IBL which could also be used in the PD courses while conveying a clear picture of IBL to teachers. Fig. 1 shows the agreed definition. 


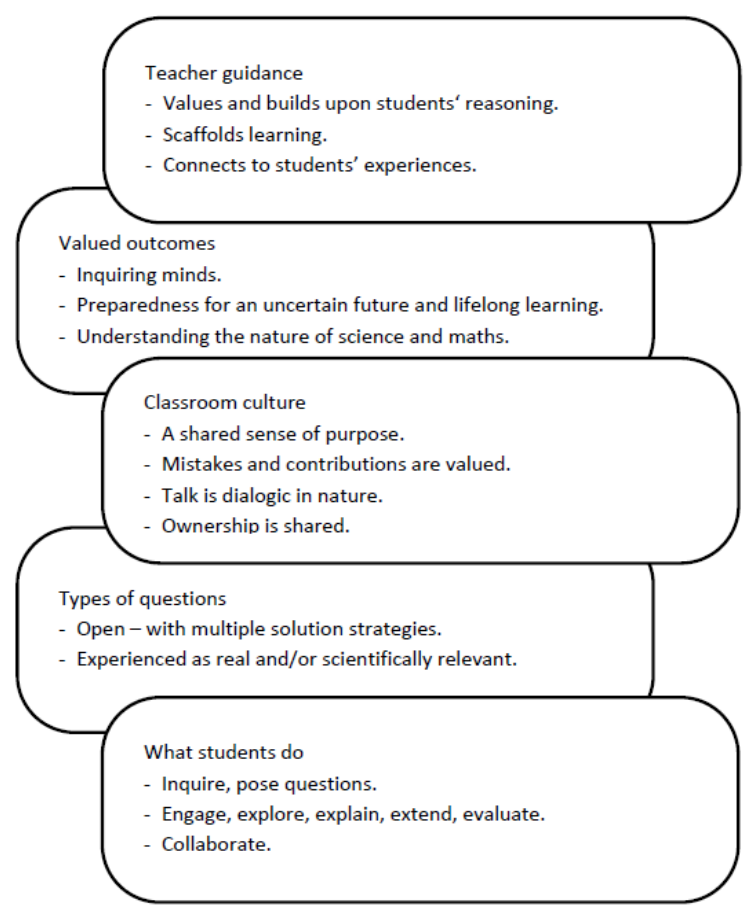

Figure 1. Definition of IBL in Primas

The following example will illustrate our understanding of IBL in class. The pictures (Fig. 2 and 3) show the construction of a house in Honduras, which is now a centre for a secondary education programme. To build the house they first collect plastic bottles, fill them with sand and then build the houses with them.
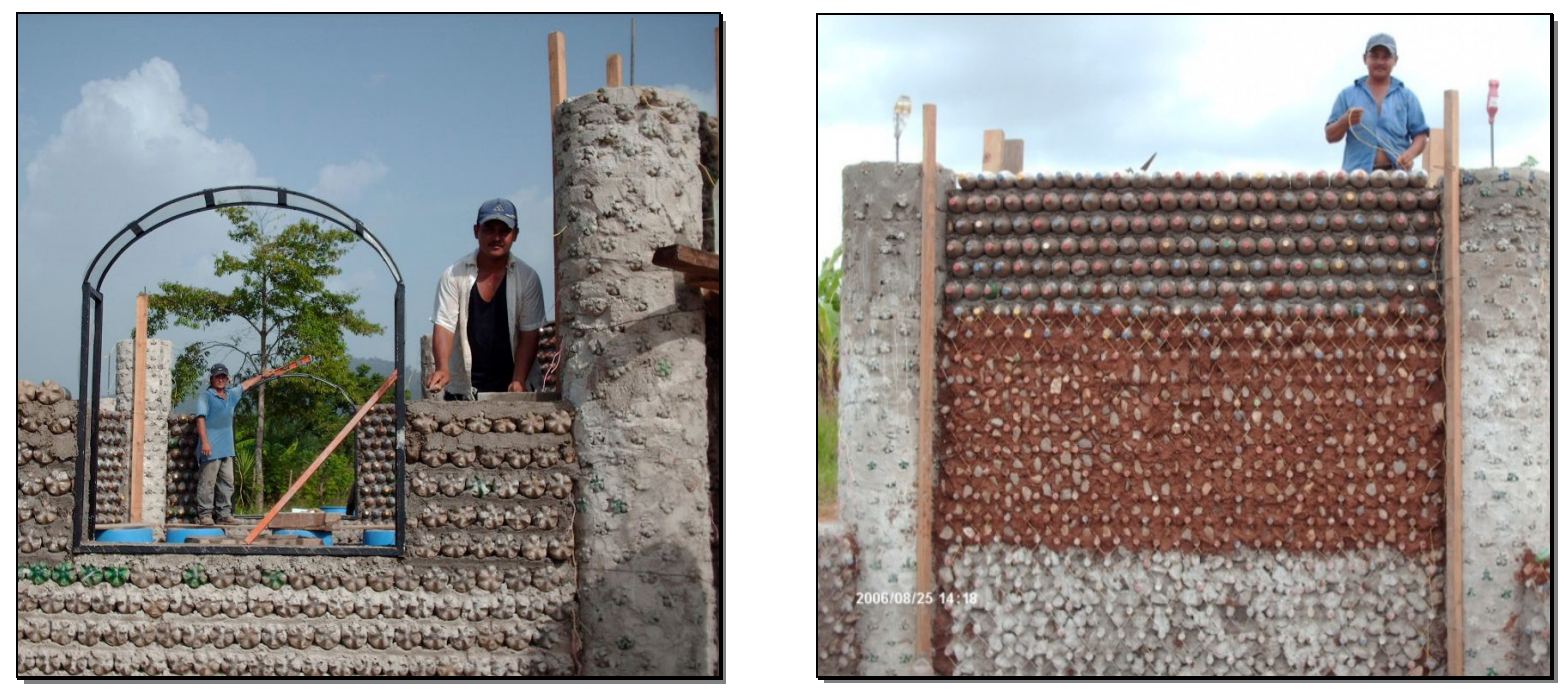

Figure 2 and 3. Building house out of plastic bottles in Honduras

In a mathematics lesson the teacher could first ask students to develop their own questions in relation to the situation in group work. Questions would then be collected on the blackboard and structured according to whether they can be answered with the help of mathematics or not. Afterwards students could decide for one question to answer, e.g. the question of how many plastic bottles are needed to build such a house. Students would then work in groups to investigate the problem and seek for solutions. Depending on how familiar the class is with IBL, assumptions could be first discussed in class or the students could continue directly in groups to estimate the number of bottles per row, the number of rows and so on. After calculating the number of bottles needed, they would communicate their solutions in class. Then, either in group or in class discussion students could reflect on the solution and validate it.

In such a lesson, teachers are required to shift towards a collaborative orientation, in which students work together with the teacher on challenging tasks. Here, the teacher's active role (following our socio-cultural approach to learning, see above) includes making constructive use of students' prior knowledge, challenging students through probing questions, 
and encouraging the discussion of alternative viewpoints, etc. (Dorier \& Maass 2012; Swan 2006). When comparing this approach to the above-mentioned transmission-based approach, the role of the teachers changes significantly (Swan 2005, 2007). Instead of prescribing all methods, correcting mistakes immediately and being in control of all work done in the class, the teachers now have to be open to different paths to solutions students might present and they need to restrain themselves from reacting immediately to students' mistakes and to have confidence in students' competences. Thus, the shift towards such an approach is challenging for many teachers because it requires new teaching competences and a change of their perspective on mathematics teaching (cf. Maass 2009, 2011).

Second, changing from transmission-based teaching to IBL is not only a matter of teachers' competences but also the school context, which does not always support such a change. Often the external assessment does not include IBL and in a tradition of "teaching to the test", IBL is left behind. Further, the head of school might not support IBL but focuses on other issues like avoiding the cancellation of lessons. There might be limited possibilities of collaboration with colleagues, and teachers' workload or a lack of resources might hinder the implementation of IBL (Dorier \& Garcia 2013; Engeln, Euler \& Maass 2013; Maass 2011).

Third, we know that there is a close connection between teachers' beliefs about teaching and their enacted teaching (see e.g. Stahnke, Schuler, Roesken-Winter 2016) and this can add to the challenges regarding the implementation of IBL. Teachers' beliefs on mathematics teaching range from considering mathematics teaching as explaining mathematical rules and algorithms and students' mastering well-rehearsed examples, to considering mathematics as problem-solving and supporting their students in solving these problems (Maass 2009, Pehkonen \& Törner 1996). In relation to modelling, a student-centred teaching approach with connection to reality and similar features as IBL, Maass (2011) found that teachers' prior beliefs on mathematics teaching influence their attitude towards modelling and their perceived enactment of a more student-centered way of teaching.

Summing up, we can see that the implementation of IBL in day-to-day classroom teaching is indeed a challenge, because teachers need new competences, the school context might not be supportive and teachers' beliefs might prevent teachers from implementing it. These challenges of implementing IBL in day-to-day teaching need to be taken into account when educating course leaders who are supposed educate other teachers to implement IBL.

\subsection{Professional Development of Course Leaders}

The professional development of course leaders, who are teachers at the same time, can be seen as being nested in three domains (Luft \& Hewson 2014):

1) In the School Domain the focus is on students' learning of content distributed by the teacher;

2) In the Professional Development Domain the teacher becomes a learner supported by a course leader;

3) In the Leadership Development Domain the future course leader acts as a learner learning to lead.

Consequently, this creates the specific situation that a course leader has to teach two different target groups (students and teachers) and their learning happens at two levels (as a teacher and as a course leader).

The aim of the German Primas' course leader seminar was to enable course leaders to run high quality PD courses on IBL. As they had almost no experience with IBL they also had to learn to implement IBL in their own classes. In the following, we will first turn to the learning on level 1 as a teacher and then to level 2, learning as a course leader.

\subsubsection{Learning as a Teacher}

Teachers' professional development is related to changes in teachers' professional knowledge and competence. In this respect it comprises teachers' content knowledge (knowledge about the subject), pedagogical content knowledge (knowledge about how to teach the subject, and pedagogical knowledge (Shulman 1986), teachers' classroom practice (Clarke and Hollingsworth 2002), as well as teachers' beliefs, motivation, and competence in self-reflection (Baumert \& Kunter 2013).

The question of at what point teachers' professional development starts (e.g. with their beliefs or classroom practice) has been discussed with some controversy (cf. e.g. Maass 2011). Here, we follow Clarke and Hollingsworth (2002) and their interconnected model of change: A change environment consists of the personal domain (knowledge, beliefs, attitudes), the domain of practice (professional experimentation), the domain of consequences (salient outcomes) and the external domain (an external source of information or stimulus). The change process can begin and end at any point in the model.

One means of supporting teachers in their professional development are PD courses (Joubert \& Southerland 2009). With the intention of supporting the delivery of high-quality PD courses, quality criteria for PD have been set up based on literature reviews of research studies (cf. Lipowsky \& Rzejak 2012). Altogether, PD courses should: 
- Combine different phases of learning and be long-term: There should be phases of learning off-job in seminars and phases of learning on-job at school (Lipowsky \& Rzejak 2012) to allow teachers to try out in school what they learn in the in the course and later reflect on it.

- Foster teachers' reflection on their own beliefs about the nature of mathematics, mathematics teaching, and their teaching experiences (Barzel \& Selter 2015).

- $\quad$ Be participant-orientated: They should take teachers' individual needs into account (Guskey 2000)

- Be relevant for their teaching practice, for example by experiencing new tasks and methods by themselves or by analyzing particular teaching situations (Barzel \& Selter 2015).

- Stimulate cooperation between teachers (McLaughlin \& Talbert 2006) so as to support them in the learning-on-job phases and to provide support even after the PD course ends.

The international Primas PD model (and the course leader seminar regarding learning as a teacher) was designed based on these quality criteria. In the PD sessions across all partner countries, participants worked on classroom activities that illustrated the pedagogical challenges of IBL, watched other teachers using these same activities through use of video and also analysed related students' documents. In the learning on-job phase, participants were encouraged to adapt and use the activities in their own classrooms. Finally, in the next session, teachers met to share classroom experiences and discuss the pedagogical implications starting off from teachers' beliefs. Additionally, they reflected on challenges in relation to the school context and how to overcome them (see 2.1).

This cyclic process (Swan, Pead, Doorman \& Moolddijk, 2013, Maass \& Doorman 2013) was repeated at each session, as new pedagogical issues were addressed. In particular, we addressed teachers' concerns about IBL and impediments to the implementation of IBL (see 2.1).

The PD activities designed for Primas comprise seven modules (see Table 1). They were designed by the English project partners in close cooperation with the Dutch partners (Swan, Pead, Doorman \& Moolddijk, 2013). In order to develop materials of high quality, all other partners gave feedback to the modules in all design phases). Modules 1 and 2 introduced teachers to inquiry-based learning, Module 3 showed how IBL can be connected to the content of the curriculum, modules $4-7$ focused on the role of students and teachers as their roles change when doing inquiry (see above) (Table 1). Due to the modular structure of the PD course, the sequence could be change up to a certain limit, e.g. modules $3-6$ could easily be permutated, whilst module 1 and 2 should be carried out at the beginning and module 7 towards the end.

Table 1. Topics addressed in the Primas PD course

1 Student-led Inquiry

2 Tackling Unstructured Problems

3 Learning Concepts through IBL

4 Asking Questions that Promote Reasoning

5 Students Working Collaboratively

6 Building on What Students already Know.

7 Self and Peer Assessment.
Presenting teachers with phenomena and inviting them to pose and pursue their own questions.

Comparing structured and unstructured versions of problems and considering the demands and challenges unstructured problems present in the classroom.

Considering how the processes of IBL might be integrated into the teaching of content.

Reflecting on characteristics of questioning that encourage students to reflect, reason, and provide extended, thoughtful answers (focus on teaching methods).

Reflecting on the characteristics of student-student discussion that benefit learning the teacher role in managing discussion (focus on teaching methods).

Considering the different ways teachers might use formative assessment to make effective use of students' prior knowledge and to support students. (focus on teaching methods).

Considering how to encourage students to take more responsibility for their own learning of IBL processes and to assess and improve each other's work?

In order to illustrate what happened in the sessions, I describe module 1 "student-led inquiry and modelling" more closely. As this was the introduction into inquiry, participants were first asked to explore a phenomenon: They were given three cups of different shape and asked to explore their rolling behavior, to ask themselves related questions and then try to answer them. After this group work they were asked to reflect on the different steps of their proceeding. In the second activity, they were asked to pose questions regarding situations given in photographs and then exchange the questions they found. By this interaction they became familiar with an important step of IBL, namely posing questions. In the next activity, they watched and analysed a video-taped lesson about the "Plastic bottles in Honduras" problem. Finally, they were asked to cooperatively design their own lesson on this problem so as to implement it in their day-to-day teaching before the next seminar and to reflect on it. 


\subsubsection{Learning as a Course Leader}

Turning to course leaders' learning on level two, parallels can be identified: Whilst the teacher has to identify challenging mathematical content for students, manage students learning, and be sensitive to students (Jaworski 1992, 1994), the course leader has to identify challenging content for teachers, manage teachers' learning, and be sensitive to teachers (Zaslavsky \& Leikin, 2004). Therefore, and due to the lack of research regarding the education of course leaders, it seems natural to adapt the design principles for teachers' PD to course leaders' PD (cf. Rösken-Winter et al. 2015). If this approach is followed for the principles as listed above, it is apparent that courses for mathematics course leaders should additionally:

- $\quad$ address skills in PD management - competence-orientation (Roesken-Winter et al. 2015);

- $\quad$ be long term and allow course leaders to learn off-job in seminars and on-job when running PD courses through reflection on their practice (Müller 2003);

- foster reflection about their teaching in the PD course (Roesken-Winter et al. 2015);

- $\quad$ start off from participants' needs regarding their role as a course leader and involving them in the planning of the course - participant-orientation (ibid);

- be relevant for PD practice, meaning they should engage course leaders in the same reflective tasks course that leaders would use with the teachers (Koellner, Jacobs \& Borko 2011) and make course leaders experience different methods as learners (Jackson et al. 2015, Roesken-Winter et al. 2015);

- $\quad$ stimulate cooperation between course leaders in planning, testing, and reflecting on PD courses (Roesken-Winter et al. 2015).

The German course leader seminar, on which I report in this paper, was based on these principles. It started in 2011 one year before they would run their first PD course and accompanied them for a more than a year while they were giving their own PD courses (long-term combination of different phases of learning). To ensure a close connection to educational theory and relevance to practice, a school teacher / university educator tandem team led each course and asked in group discussions and questionnaires after each PD day for participants' needs and wishes for the next session (participant-orientation).

As future course leaders, the participants themselves experienced the modules designed for our PD courses (relevance for practice). However, the German team did not want the course leader to simply use the modules as they were encountered and without reflection, but rather expected them to use and adapt modules according to their participating teachers' needs in the sense of reflective rationality (Krainer 2015). In other words, course leaders were themselves expected to act autonomously and help their teachers reflect on own practice. Therefore, when using the PD modules described above in the course leader seminars, they also reflected on their use in PD courses (e.g. following on from the questions: What are the aims of this activity? For what kind of teachers is it useful? How will teachers react to this activity? etc., foster reflection). We also used a large variety of different instruction formats suitable for adults (e.g. think-pair-chair, world café) and reflected on using them in PD (relevance to practice, foster reflection). To support taking up the new role of a course leader, we discussed how to plan a PD course and gave participants the possibility to simulate their new role in one session. Within the seminars we also used certain situations for reflection about the two roles between which participants had to switch. For example, when course leaders - learning as teachers - discussed the issue of IBL taking too much time and not being feasible, we stopped and asked them how they would react to such a situation in their PD courses. Additionally, in the second year, the programme included reflection about the PD course that leaders held themselves, and discussed their challenges (participant-orientation). To stimulate cooperation, pairs of course leaders did team teaching in their PD courses. They were also encouraged to exchange experiences about their practice with other course leaders within the seminar phases. Table 2 gives an overview about the schedule. 
Table 2. Overview about schedule of course leader seminar and PD courses

\begin{tabular}{|c|c|c|c|c|c|}
\hline & $01-06 / 2011$ & $07-12 / 2011$ & $01-06 / 2012$ & $07-12 / 2012$ & $01-06 / 2013$ \\
\hline $\begin{array}{l}\text { Learning as a } \\
\text { teacher }\end{array}$ & $\begin{array}{l}\text { 24/03/2011: Module } 1 \\
\text { 25/03/2011: } \\
\text { Module 5 \& } 4 \\
\text { 13/05/2011: } \\
\text { Module } 3\end{array}$ & & $\begin{array}{l}\text { 12/03/12: } \\
\text { Module 2, } \\
\text { 21/05/12: } \\
\text { Module } 7\end{array}$ & $\begin{array}{l}\text { 16/10/2012: Module. } \\
6\end{array}$ & \\
\hline $\begin{array}{l}\text { Learning as a } \\
\text { course leaders }\end{array}$ & $\begin{array}{l}\text { Reflections about these } \\
\text { modules on the course } \\
\text { leader level as described } \\
\text { above }\end{array}$ & $\begin{array}{l}\text { 29/09/2011: } \\
\text { Simulation of a PD } \\
\text { course; } \\
\text { 25/11/2011: } \\
\text { Reflection on course } \\
\text { leaders aims for their } \\
\text { PD; on } \\
\text { how to plan their own } \\
\text { PD course \& planning } \\
\text { the course }\end{array}$ & $\begin{array}{l}\text { 12/03/12: Reflection on } \\
\text { Module } 2 \text { and reflection on } \\
\text { the first PD course of the } \\
\text { course leaders } \\
\text { 21/05/2012: Reflection on } \\
\text { Mod. } 7\end{array}$ & $\begin{array}{l}\text { 16/10/2012 } \\
\text { Reflection on } \\
\text { Module } 6 \text { and prior } \\
\text { PD courses }\end{array}$ & $\begin{array}{l}\text { 13/02/2013: } \\
\text { Reflection of } \\
\text { challenges the } \\
\text { course leaders were } \\
\text { facing } \\
\text { Planning of the last } \\
\text { PD courses } \\
\text { 19/06/2013: Closing } \\
\text { session: } \\
\text { Reflection on the } \\
\text { overall course leader } \\
\text { seminar }\end{array}$ \\
\hline $\begin{array}{l}\text { PD courses } \\
\text { ran by course } \\
\text { leaders }\end{array}$ & & & $\begin{array}{l}01 / 2012: \\
\text { Start of PD courses }\end{array}$ & & $\begin{array}{l}06 / 2013: \\
\text { End of PD courses }\end{array}$ \\
\hline $\begin{array}{l}\text { Data } \\
\text { collection }\end{array}$ & & & & & $\begin{array}{l}\text { Interviews after last } \\
\text { session }\end{array}$ \\
\hline
\end{tabular}

3. Methodological Approach

\subsection{Design Research}

A design research approach was selected for this study. Design research aims at designing interventions based upon theoretical propositions, and incorporates iterative cycles of design, evaluation, and revision (Kelly 2006).

In Primas, we wanted to design a course leader PD for practical use. The aim of the exploratory study we present here was to see to what extent the carefully designed seminar met the needs of the course leaders, and to optimize the course accordingly.

The design of the course leader PD was based on the quality criteria for teachers' PD, which were transferred and extended to use them for course leaders' seminars. Cyclic approaches of design, evaluation, and revision were included. Two cycles of evaluation by the German team members and an external group of experts (e.g. representatives from school authorities, teacher educators) led to a third version, which was used for the implementation from March 2011 to June 2013. After implementation, a subgroup of the German team including the author, conducted the retrospective analysis reported here.

\subsection{Data Collection}

The German research team decided to use semi-structured interviews, as all research questions concerned the teachers' perspective on taking up their role as course leaders. Semi-structured interviews serve the purpose of reconstructing a person's perspective in an explorative way (Flick 2012). We decided for retrospective interviews as our research questions aimed at course leaders' perspectives after gaining experience in running PD courses.

The interviews all followed the same interview guide (Appendix). The schedule contained questions about participants' perspective on IBL and related challenges, on the course leader PD, on up-taking of the new role, and on the PD courses they, themselves, later held.

\subsection{Sample}

Our study was a small scale exploratory study. All participants were mathematics teachers, had volunteered for running PD courses, and had almost no experience in teaching IBL. The sample size was $\mathrm{N}=8$ out of 20 course leaders, which were basically all course leaders willing to give interviews (see table 2). This might have biased the results (as for example those considering themselves as not successful might have restrained from interviews) and will be discussed in the limitation section. 
Table 3. Sample of the explorative study

\begin{tabular}{llll}
\hline $\begin{array}{l}\text { Taking over the role of a } \\
\text { course leader } \downarrow\end{array}$ & $\begin{array}{l}\text { Inexperienced in adult } \\
\text { education }\end{array}$ & $\begin{array}{l}\text { Not experienced in } \\
\text { teachers' PD, but } \\
\text { experienced in adult } \\
\text { education in another field } \\
\text { Kurt }\end{array}$ & $\begin{array}{l}\text { Experienced in teachers' } \\
\text { PD }\end{array}$ \\
Challenging & $\begin{array}{l}\text { Rolf } \\
\text { Rainer }\end{array}$ & Sigrid & Wiebke \\
Neutral & Ruth & Burgunda & Bastian \\
\hline
\end{tabular}

3.4 Data Analysis

A coded evaluation of the interviews was carried out by German research team using some of the principles of the 'Grounded Theory' approach (Strauss \& Corbin, 1998), which aims to create new hypotheses based on new data and is there seems appropriate for an explorative study. Unfortunately it was not possible to collect more data during the data gathering process and its evaluation ('theoretical sampling') due to having only a static set of eight interviews (Strauss $\&$ Corbin, 1998). The two principles of grounded theory that were used are:

1) The principle of openness: Theoretical assumptions should not be made a priori; they should be developed throughout the process (Strauss \& Corbin, 1998).

2) Theoretical coding: Theoretical coding is done by assigning codes to the empirical material. When coding phenomena, cases and terms are compared in order to obtain a deeper understanding of the facts of a case. An important aid when coding is the writing of memos (Strauss \& Corbin, 1998). These help researchers to go beyond a mere description, analysing the cases instead, and they could form the foundation for the final draft.

More concretely, we proceeded in four steps:

1. Open coding: In a first step, three interviews were analysed using open coding. Open coding is the first part of theoretical coding in which data is analysed critically by using many open codes (here so-called "in vivo codes" are taken directly from the text). For example, if a course leader says: "We were just experiencing IBL ourselves," one can then use "Just experiencing IBL ourselves" as a code. In so doing, the text is questioned frequently so as to avoid simple paraphrasing. Memos were written, thereby noting down important ideas.

2. Case descriptions: In order to get a closer look at the individual cases, brief case descriptions of the analysed cases were written.

3. Axial coding: Based on the insight provided by the first two steps, axial coding (second step of theoretical coding) was carried out. Within the axial coding, the open codes gained during open coding are arranged axially into categories. It is very important to investigate any connections between these categories and their meaning (e.g. cause and effect, ways and means) in order to gain further insight (Böhm 2002). The categories as well as related sub-categories used for axial coding are shown in the Annex.

\section{Results}

In the following, I will outline the results following the research questions.

\subsection{What Needs Did Participants Express as Teachers Learning to Use IBL?}

Despite the fact that the course leader seminar was designed to have a practical relevance (in particular as regards to teaching IBL, see 2.2), some of the course leaders, learning in the professional domain as a teacher, demanded a higher practical relevance, as e.g. Kurt put it: "Maybe it was underestimated a bit how big the step is from this IBL in principle to implementing it in day-to-day teaching." (Kurt, 8-14) ${ }^{1}$.

One issue in this respect was the demand of getting more tasks:

For me the focus was too much on developing tasks in this area than to have a look what tasks exist already."(Rainer, 95-106). In other words, I have the topic fractions [...] and I want to design something using Primas principles. And then I have the difficulty how to find a suitable task which provides the content addition in fractions. [...]" (Rainer, 179-188)

Other participants referred to ideas ready for use in class the next day (Wiebke, 75). Altogether, the results indicate that participants' needs as regards the practical relevance criterion were quite high.

\footnotetext{
${ }^{1}$ The numbers in brackets refer to the part of the interview quoted.
} 


\subsection{What Needs Did Participants Have in Relation to Their Preparation as a Course Leader?}

As opposed to the strong demand as regards the practical relevance when learning in the professional domain, participants seemed to be quite content as regards learning in the leadership domain. All in all, 6 of the 8 course leaders interviewed, said that they felt well prepared by the course leader seminar. In particular, 7 emphasized that they appreciated running the courses in tandems (which means that always two course leaders ran one PD course together):

„For us, it worked wonderfully. [...] It was good because she is solely teaching primary school and I sometimes work at a secondary school, too. For that reason, we could cover the whole spectrum of the group we got assigned. [...] We prepared all PD courses together (Bastian, 33).

Other course leaders referred to the work in tandems as reducing the workload (Wiebke, 36) or facilitating taken over the new role as a course leader (Kurt, 24-33).

Additionally, all participants also appreciated the simulation of a PD session, the sessions on how to plan a PD activity, the planning of their PD course within the seminar, the PD materials provided for direct use in their PD and the continuation of their course leader seminar whilst they ran the PD courses. This feedback indicates that the course leader seminar was apparently heading in the right direction with its concept of preparing participants to become course leaders.

Despite the overall contentment with the seminar expressed by the course leaders, the data analysis points to two major challenges the course leaders faced; one connected to taking up the role of a course leader, the other that they had to learn about teaching IBL as teachers whilst almost simultaneously teaching other teachers to do so. The latter was considered a challenge by five participants, but to differing extents. The following three quotations show the range of perceived difficulties:

“...it was a bit like jumping in at the deep end. Because on the one hand, we were just experiencing those difficulties with the implementation of such open tasks in our teaching ourselves and on the other hand, as course leaders, we should have those experiences on hand already." (Kurt, 24-33)

"It was new for me that it [IBL] was something unknown to me, too. Well, [...] if you do something new, if you change something, you ask yourself "Was this an open task? [...] Then you don't feel far away from your colleagues, because it was new to me as well. Therefore, I think we were on the same wavelength." (Sigrid, 65-69)

"It is a challenge [...] to try out new things. But it is also it is also a gain because you have to be open for new ideas, new thoughts, new pedagogies [...] and you need the will to do this [...] to say I try it. (Bastian, 59)

Obviously, Kurt saw a big challenge in learning to teach IBL and having to run a PD on it, as he talked about "difficulties" and "jumping in at the deep end". His remark that he needs to have the experiences at hand might also indicate that he perceived the role of the course leader as someone who needs to have a clear advance in knowledge. The situation seemed to be less difficult for Sigrid. She expressed uncertainty, but then turned it into a positive aspect by saying that she felt on the same wavelength with teachers. Apparently, her demand for an advance of knowledge was not as big as for Kurt. Nevertheless, she also highlighted how important it was for her in this respect, that the course leader seminar ran parallel to their teacher PD courses (Sigrid 81-89). At the other end of the scale, Bastian did not talk about difficulties with IBL but the will to try it. At another point, he also explicitly pointed out that he did not have any problems in running the PD courses. One reason for this might be that he adopted the IBL approach quite quickly; another might be that he has been running PD courses in biology for 10 years and therefore only had to learn in the professional domain as a teacher of mathematics and not so much in the leadership domain as a course leader.

The second challenge which also derived from their double role as teachers and course leaders was the fact that they had to teach their colleagues. Here, five of the course leaders identified difficulties as the following quotations illustrate:

"The big difference is the high regard I have for the experience [of my colleagues] [...]. With pupils, my experience as a teacher tells me roughly [...] what they can do [...] With colleagues it's so much different. [...] They come with an incredible wealth of experiences, trained professionals with many years of experience. (Kurt, 213-225)

[...] And then you have the feeling, yes, now you are responsible for that, for the time the people invest. Pupils aren't interested in many things too but there I know, ok, it's in the curriculum." (Rolf, 65-68)

Apparently, these participants seemed to differ between students and teachers as regards the esteem of prior knowledge and the necessity of doing something relevant. Rolf's remark about the time people invest also indicates that he is well aware of the workload of teachers and the context in which they work.

\subsection{How Did Participants Perceive Their Role as a Course Leader?}

The results indicate that participants' perception of the role in many cases was mediated by their way of focusing either 
on differences or on commonalities as regards both roles. Evidently, those focusing on commonalities did not have problems in taking up the new role.

I don't see a big difference [...]. It is on a different level and you have to use a different language. There are colleagues sitting in front of me [...] But the difference is not big. [...] I was aware of that, but it was nothing I was afraid of. (Burgunda, 198-208)

Those focusing on differences either seemed to find a way to take up the role or not, depending on the way in which they tried to take up the role. For Kurt, the beginning seemed to have been very difficult as for as he talks about "jumping in at the deep end" (see above). All in all, he seemed to focus on the differences between the two roles, as can be seen by e.g. his explicit differentiating between students and teachers (see above) and the following quotation: „Naturally, professional development for grown-ups, in this case colleagues, differs from the preparation of teaching in class...". (Kurt, 193-207).

As opposed to Kurt, after a challenging beginning, Rainer seems to cope quite well:

"In particular, at the beginning it was more exciting than going into a class. But I liked it the more the more I did it. It was fun, because it was a completely different way of working than with a class. We had an exchange about pedagogies on par." (Rainer, 64-67)

Bastian seemed to fill the role of a course leader in a similar way and to be very much at ease with it:

Well, I would say it this way, primus inter pares. In our PD there was never such a situation that I'm standing in front of them and deliver a keynote speech and they have to accept it [...]. It was more at eye level. [...] Sometimes I didn't feel like a course leader. But more like a colleague who has new ideas, made new experiences, he wants to share. (Bastian, 17)

Bastian seemed to have a clear vision of his new role. In line with the Primas' understanding of using the IBL approach, he seemed to restrain himself from standing in front of his colleagues telling them what to do, and used a more collaborative approach in his courses. Unlike Bastian, Rolf did not seem to adapt the role of the course leader during the whole time. "Yes, I thought the legitimation to be difficult, which was also demanded by the other teachers. Why are you standing in front of us attempting to tell us something?... " (Rolf, 65-68)

His phrasing "Why are you standing in front of us..." might indicate, that his mental image of a course leader is indeed the image of a person who stands in front of teachers to tell them what to do (cf. Jackson et al. 2015). From the eight participants interviewed, four took up their role in a similar way as Bastian did, two did not see many differences, and one more took a perspective similar to Rolf's.

\subsection{To What Extent Were the Course Leaders' and the Teachers' Role Intertwined?}

Some results indicate that the roles of the teacher and the course leader were often intertwined. This became evident when looking at course leaders' comments regarding their participation in our course leader seminar, their learning as teachers and the comments from teachers participating in their courses as reported by the course leaders themselves. The similarities were striking.

The quotations of Rainer and Wiebke illustrate the issue. "Well, I always want to have a theoretical part but I always want to have a huge practical part too, so I can say I'll try it tomorrow.[...] And my participants seem to be the same." (Wiebke, 75-75)

As we have already seen above in relation to research question 1, Rainer was looking for tasks which ensure students' learning of certain content of the curriculum and struggling to combine IBL with this, a typical perspective on mathematics teaching (cf. Maass 2009, 2011). Later, he stated about the teachers in his PD course: "Well, they have similar points of criticism, [...], what I said as well. [...] they see the same problem with the implementation into the day-to-day teaching. How do I combine [...] the topics of the curriculum with [IBL]”. (Rainer, 212-220)

Bastian seemed to take advantage of his double role. As a teacher, Bastian seemingly knew that teachers often want tasks for their day-to-day teaching: "They want something practical for their lessons. Come on, show us how you did this in a concrete way." (Bastian, 15) As a course leader he looked for ways to respond to their needs:

,We all brought math books [...] and said, have a look where open tasks are. [...] Where do I have really open tasks? And afterwards we collected them and bound them for everyone and they could take it home as a task-collection." (Bastian, 47)

Bastian had apparently taken perspective that he, as a course leader, should respond in an active way to teachers' needs. This might be due to the fact that Bastian was already quite experienced in running PD. However, Sigrid, with less experience, seemed to take a similar perspective (Sigrid, 240-265). 
The strong connection between the role of the course leader and the role of the teacher is to some extent a natural consequence of the double role they have. Some results might also indicate that the role of the teacher seemed to be the stronger role: When asked about the experiences they gained as teachers and course leaders, many of our course leaders reported only on their experiences they gained as teachers and not as course leaders (e.g. Burgunda, 11-21).

\section{Discussion}

In this design research study, a course leader seminar was developed in order to scale up mathematics teachers' professional development on IBL. The study considered the special case of German course leaders who still work as teachers whilst running PD courses as an add-on to their day-to-day teaching. Although carried out in the specific case of the German Primas project, this explorative study sheds light on the needs these course leaders have and how they perceive their role as a course leader. In the following, I discuss issues related to the dual role of these course leaders. This will help to suggest optimisations for the design of the course leader seminar.

Currently little is known about what qualifies someone to be an effective PD course leader (Ball \& Even, 2009; Krainer, Chapman, \& Zaslavsky, 2014) and specifically how to design a course leader seminar. On a theoretical level a parallelism or even sameness between learning as a teacher and learning as a course leader was identified (Zaslavsky \& Leikin 2004), which can be used for setting up quality criteria for course leaders PD (cf. Roesken-Winter et al, 2015). These quality criteria were used in the design of the course leader seminar reported here. The results of this study indicate that the theoretical parallelism cannot be transferred directly to practice regarding the design of course leader seminars.

Although some of the teachers did not see big differences between the role of a teacher and the role of the course leaders, others saw big differences between the two roles and therefore perceived taking up the new role as a challenge, as also highlighted by Krainer (2015). These teachers in particular distinguished very clearly between students as learners in their class and teachers as learners in their PD course. They seem to have a big respect for the experience the other teachers have or feel a high responsibility for engaging teachers in something they consider as relevant, whilst this does seem to be true for the teaching of students. This can be seen in connection to the double role the course leaders have: In their role as a teacher, they know about working conditions of teachers (e.g. experienced shortness of time, need to fulfil the curriculum, see 2.1,) and their expectations on PD (e.g. relevant for direct use in class, see 4), in their role as a course leader they feel they need to address these issues. They also know about the long German teacher education (4-5 years at University and 1-1.5 years induction phase) and the experience that their colleagues have. Possibly, they consider the course leaders' seminar to be too short in comparison with the teacher education, which might lead to a high esteem for their colleagues' experience and the problem of legitimation.

The way in which participants see their role as a course leader might also support taking up the new role. Those, who referred to working with the PD participants on the basis of parity, did not highlight many problems. Unlike them, another teacher, who referred to standing in front of other teachers and telling them what to do, referred to problems of legitimation. Apparently, the different possibilities to take up the new role as a course leader need further attention in planning a course leader seminar, a matter discussed in the next section.

The double role as a teacher and a course leader can lead to intertwining between the two roles. Some course leaders' perceptions of PD participants needs seemed to be biased by their own perception of PD courses as participants, and again this needs further attention as is outlined below.

Additionally, the results indicate that the teacher role often is the stronger role. This of course does not come unexpectedly, as the participants of the course have been a teacher for much longer. They have gained many more experiences as a teacher, are in contact with many other teachers and have a learning trajectory as teachers (Wenger 1998), whilst the adopting the new role and bridging between both roles indeed is a challenge (Krainer 2015).

The stronger role of a teacher might also be a reason why the needs made explicit by the teachers were so much stronger in the domain of professional development domain than in the domain of leadership development (cf. Luft \& Hewson 2014 see 2.2). It might be also linked to the fact that they have much more experience as a teacher and exactly know what they need here.

In the professional domain teachers emphasized in particular their strong wish for practical relevance: They asked for IBL task collections and tasks for direct use in class. This wish can be connected to the school context, which does not always support the implementation of IBL, and in particular teachers' high workload (see 2.1). This result is also in-line with the studies of Roesken-Winter et al. (2015) and Jackson et al. (2015) who found that course leaders more strongly emphasize a practical perspective in PD courses. Our course leaders also highlighted the difficulties regarding the implementation in day-to-day teaching practice, hereby apparently referring to the school context. Perceiving the school context as a challenge can be considered as also being connected to their beliefs (see 2.1). 
As already seen, the specific situation of learning both as a teacher and as a course leader can lead to the particular challenge of course leaders who need to teach a certain pedagogical approach without having much experience about it. This challenge was rated differently by course leaders and apparently related to way they understood their role as course leaders and to the challenges they faced when implementing IBL.

Consequently, this explorative study illuminates in detail the needs and challenges of IBL PD course leaders, who are teachers and course leaders at the same time and therefore contributes to building knowledge in respect of the education of course leaders.

\subsection{Designing PD Courses for Course Leaders}

This study, though small, also supports the German Primas team in optimizing the course leader seminar concept, thereby following the design research approach. The following reflections are based on the results of the study, but are by no means necessary consequences for the design, as there is no general silver bullet to PD (Krainer 2015). Naturally, any new concept developed based on these results would need to be evaluated in turn.

As regards taking over the role of a course leader, several challenges were identified. These were that IBL is new to course leaders as well; having to teach colleagues; different ways of taking up the new role and the intertwining of roles. Apparently, the measures taken in the PD course leader course, though heading in the right direction should be extended by offering course leaders rather more opportunities for identification with the new role. In section 2.2, it was argued that the course leader PD should follow the quality criteria on both levels, for teacher and course leader education. Apparently, the level of course leader education needs much more attention in this respect.

A first step would be to provide stronger support to course leaders in the development of their competences in running such a course. This would make them feel more secure and offer them more possibilities to take up the role of a course leader. This relates in particular to the criterion of being relevant to practice, in this case PD practice. A second step would be to foster reflection on the role of a course leader much more. The two steps are now elaborated in more detail.

Turning to the first step, the following examples illustrate how this could look like: If teachers are supported in leading student discussions (as in Module 5), course leaders should also be supported in leading teachers' discussions without it being taken for granted that they do the transfer themselves. This is in line with the design of the course leaders' seminar from Jackson et al. 2015. Also, a PD course for course leaders should include analysing cases from PD sessions, video sequences from PD sessions (also in line with suggested design from Jackson et al. 2015) and teacher documents (e.g. lesson plans written by other teachers) and not be restricted to cases from classroom teaching and students' documents (as was done in almost all modules).

Furthermore, course leaders could be asked not only to plan PD but also to present and discuss it in the course (relevance to PD practice). Although course leaders reflected on their experiences after their PD courses, the spiral model could be adopted (see 2.2) not only for lessons but also and more strictly for PD sessions, by analyzing PD sessions in the seminar, then implementing them and later reflecting on them. This requirement points in the same direction as Koellner, Jacobs and Borko (2011), who identified a need for more reflection.

Turning to the second step, I would recommend explicitly including a new quality criterion for course leaders' seminars: "Fostering reflection on the new role of a course leader in order to support course leaders in taking up the new role in an appropriate way". This is in line with McGatha (2008), who investigated school-based coaches outside of mathematics, and highlighted the importance of defining the coach's role. Therefore, a future course could include discussions about participants' concerns as regards running PD, their mental conceptions of the course leaders' role as well as connections between the role of the teacher and the course leader (so as to minimize the bias between these roles). Possibilities on how to overcome challenges (such as not having much experience in teaching IBL and having to teach colleagues) and possibilities to take up the new role as a course leader could be sought for and exchanged,.also in connection with more simulations of PD courses in the seminar.

\subsection{Limitations and Potential of the Study}

The knowledge gains of this explorative study naturally are only transferable to a limited extent, as the sample size was quite small and only refers to the first cascade of scaling up (Krainer 2015). Furthermore, the study concerned the German context and the specific case of IBL. Due to the challenges of specifically implementing IBL it cannot be directly transferred to other teaching approaches; however it might inform the design of course leader seminars for other student-centred teaching approaches. Because of the specifics of the German context, further research needs to show whether the situation is similar or not in other countries who also work with teachers as course leaders.

As participating teachers were selected on a voluntary basis, this might have also influenced the results. The study is therefore by no means comprehensive but only illustrates the impact of the course leader seminar on some course leaders. 
The potential of this small-scale study is that it provides starting points for further research illuminating what kind of support course leaders actually need to run PD courses themselves. Here it would make sense to carry out similar studies with larger samples, to research persons who have worked as course leaders for a longer time (in Germany there are the so-called "Fachberater" who still work as teachers but with a reduced amount of lessons and who run PD frequently as part of their official job), to evaluate not only the perception of the course leaders but also their enacted teaching in class and in PD, and also to research course leaders with a different educational background (e.g. teacher educators from University) so as to compare differences and similarities.

\section{References}

Artigue, M., \& Blomhøj, M. (2013). Conceptualising inquiry-based education in mathematics. ZDM, 45(6), 797-810. https://doi.org/10.1007/s11858-013-0506-6

Ball, D. L., \& Even, R. (2009). Strengthening practice in and research on the professional education. In R. Even \& D. Loewenberg Ball (Eds.), The professional education and development of teachers of mathematics - the 15th ICMI Study (pp. 255-260). New York: Springer. https://doi.org/10.1007/978-0-387-09601-8_27

Barzel, B., \& Selter, C. (2015). Die DZLM-Gestaltungsprinzipien für Fortbildungen [The DZLM design principles for PD]. JMD, 36(2), 259-284. https://doi.org/10.1007/s13138-015-0076-y

Baumert, J., \& Kunter, M. (2013). The COACTIV model of teachers' professional competence. In M. Kunter, J. Baumert, W. Blum, U. Klusmann, S. Krauss \& M. Neubrand (Eds.), Cognitive activation in the mathematics classroom and professional competence of teachers. Results from the COACTIV Project (pp. 29-55). Mathematics Teacher Education, Vol. 8. Berlin: Springer.

Böhm, A. (2002). Theoretisches Codieren: Textanalyse in der Grounded Theory [Theoretical coding: Analysis of texts in Grounded Theory]. In U. Flick, E. v. Kardorff \& I. Steinke (Eds.), Qualitative Forschung, Ein Handbuch [Qualitative research, a handbook] (pp. 475-485). Reinbek bei Hamburg: Rowohlt Taschenbuch Verlag GmbH.

Bruder, R., \& Prescott, A. (2013). Research evidence on the benefits of IBL. ZDM, 45(6) (811-822). https://doi.org/10.1007/s11858-013-0542-2

Clarke, D., \& Hollingsworth, H. (2002). Elaborating a model of teacher professional growth. Teaching and Teacher Education, 18, 947-967. https://doi.org/10.1016/S0742-051X(02)00053-7

Dorier, J. L., \& García, F. J. (2013). Challenges and opportunities for the implementation of inquiry-based learning in day-to-day teaching. ZDM, 45(6), 837-849. https://doi.org/10.1007/s11858-013-0512-8

Dorier, J., \& Maaß, K. (2014). Inquiry based Mathematics education. Encyclopedia of Mathematics education (p. 300-304). Dordrecht, Heidelberg, London, New York: Springer.

Engeln, K., Euler, M., \& Maass, K. (2013). Inquiry-based learning in mathematics and science: A comparative baseline study of teachers' beliefs and practices across 12 European countries. ZDM, 45(6), 823-836. https://doi.org/10.1007/s11858-013-0507-5

Flick, U. (2012). Qualitative Sozialforschung - eine Einführung [Qualitative social research - an introduction]. Reinbek bei Hamburg: Rowohlt.

Guskey, T. R. (2000). Evaluating professional development. Thousand Oaks: Corwin Press.

Hmelo-Silver, C. E., Duncan, R. G., \& Chinn, C. A. (2007). Scaffolding and achievement in problem-based and inquiry learning: A response to Kirschner, Sweller, and Clark (2006). Educational Psychologist, 42(2), 99-107. https://doi.org/10.1080/00461520701263368

Jackson, K., Cobb, P., Wilson, J., Webster, M., Dunlap, C., \& Appelgate, M. (2015). Investigating the development of mathematics leaders' capacity to support teachers' learning on a large scale. In: ZDM Mathematics Education, 47(1), 93-104. https://doi.org/10.1007/s11858-014-0652-5

Jaworski, B. (1992). Mathematics teaching: What is it? For the Learning of Mathematics, 12(1), 8-14.

Jaworski, B. (1994). Investigating mathematics teaching: A constructivist enquiry. London: The Falmer Press.

Joubert, M., \& Sutherland, R. (2008). A perspective on the literature: CPC for teachers of mathematics. National centre for Excellence in the Teaching of Mathematics.

Kelly, A. (2006). Quality criteria for design research: Evidence and commitments. In J. van den Akker, K. Gravemeijer, S. McKeeney, \& N. Nieveen (Eds.), Educational design research (pp.107-118). Oxford: Routledge Chapman \& Hall.

Koellner, K., Jacobs, J., \& Borko, H. (2011). Mathematics professional development: Critical features for developing 
leadership skills and building teacher capacity. Mathematics Teacher Education and Development, 13(1), 115-136.

Krainer, K. (2015). Reflections on the increasing relevance of large-scale professional development. ZDM Mathematics Education, 47(1), 143-151. https://doi.org/10.1007/s11858-015-0674-7

Krainer, K., Chapman, O., \& Zaslavsky, O. (2014). Mathematics Teacher Educator as Learner. In S. Lerman (Ed.), Encyclopedia of Mathematics Education (pp. 431-434). Dordrecht, Heidelberg, New York \& London: Springer. https://doi.org/10.1007/978-94-007-4978-8_108

Lipowsky, F., \& Rzejak, D. (2012). Teachers as learners - when is the change of roles successful. Schulpädagogik heute 3(5), 1-17. Lipowsky, F. , Rzejak, D. (2012). Lehrerinnen und Lehrer als Lerner - Wann gelingt der Rollentausch? Merkmale und Wirkungen wirksamer Lehrerfortbildungen [Teachers as learners - when is the change of roles successful]. Schulpädagogik heute 3(5), 1-17.

Loucks-Horsley, S. (2010). Designing professional development for teachers of science and mathematics (3rd ed.). Thousand Oaks, California: Corwin Press.

Luft, J. A., \& Hewson, P. W. (2014). Research on Teacher Professional Development Programs in Science. In S. K. Abell, \& N. G. Lederman (Eds.), Handbook of research on science education (Vol. 2, pp. 889-909). Routledge.

Maass, K. \& Artigue, M. (2013). Implementation of inquiry-based learning in day-to-day teaching: a synthesis. ZDM Mathematics Education, 45(6), 779-795. https://doi.org/10.1007/s11858-013-0528-0

Maass, K. (2009). What are teachers' beliefs about effective mathematics teaching?. In J. Cai, G. Kaiser, B. Perry, \& N.-Y. Wong, (Eds.), Effective Mathematics Teaching from Teachers' Perspectives: National and Cross-National Studies (S.141-162). Rotterdam: Sense Publishers.

Maass, K. (2011). How can teachers' beliefs affect their professional development? ZDM Mathematics education, 43(4), 573-586. https://doi.org/10.1007/s11858-011-0319-4

Maass, K., \& Doorman, M. (2013). A model for a widespread implementation of inquiry-based learning. ZDM, 45(6), 887-899. https://doi.org/10.1007/s11858-013-0505-7

McGatha, M. (2008). Levels of engagement in establishing coaching relationships. Teacher Development, 12(2), 139-150. https://doi.org/10.1080/13664530802038147

McLaughlin, M. W., \& Talbert, J. E. (2006). Building School-Based Teacher Learning Communities: Professional Strategies to Improve Student Achievement. New York: Teachers College Press.

Müller, U. (2003). Weiterbildung der Weiterbildner [Education of educators] (Vol. 17). Hamburg: Verlag Dr. Kovac.

Mullis, I., V.S., Martin, M. O., \& Foy, P. (2008). TIMSS 2007 International Mathematics Report: Findings from IEA's Trends in International Mathematics and Science Study at the fourth and eighth Grades. Chestnut Hill: TIMSS \& PIRLS International Study Center, Lynch School of Education, Boston College.

Pehkonen, E., \& Törner, G. (1996). Mathematical beliefs and different aspects of their meaning. Zentralblatt für Didaktik der Mathematik, 28(4), 101-108.

Radford, L. (2010). The anthropological turn in mathematics education and its implication on the meaning of mathematical activity and classroom practice. Acta Didactica Universitatis Comenianae Mathematics, 10, 103-120.

Rocard, M., Csermely, P., Jorde, D., Lenzen, D., Walberg-Henriksson, H., Hemmo, V. (2007). Science Education Now: A Renewed Pedagogy for the Future of Europe. Luxembourg: European Commission Publications Office.

Rösken-Winter, B., Schüler, S., Stahnke, R., \& Blömeke, S. (2015). Effective CPD on a large scale: examining the development of facilitators. ZDM Mathematics Education, 47(1), 13-25. https://doi.org/10.1007/s11858-014-0644-5

Shulman, L. S. (1986). Paradigms and research programs in the study of teaching: a contemporary perspective. In M. C. Wittrock (Ed.), Handbook of research on teaching (pp. 3-36). New York: Macmillan.

Stahnke, R., Schueler, S., \& Roesken-Winter, B. (2016). Teachers' perception, interpretation, and decision-making: a systematic review of empirical mathematics education research. ZDM, 48(1), 1-27. https://doi.org/10.1007/s11858-016-0775-y

Stigler, J. W., Gonzales, P., Kawanaka, T., Knoll, S., \& Serrano, A. (1999). The TIMSS videotape classroom study: Methods and findings from an exploratory research project on eighth-grade mathematics instruction in Germany, Japan, and the United States (NCES 1999-074). Washington, DC: National Center for Education Statistics. 
Strauss, A., \& Corbin, J. (1998). Basics of qualitative research. Thousands Oaks: SAGE Publications.

Swan, M. (2005). Improving Learning in Mathematics: Challenges and Strategies. Sheffield: Teaching and Learning Division, Department for Education and Skills Standards Unit.

Swan, M. (2006). Collaborative Learning in Mathematics: A Challenge to our Beliefs and Practices. London: National Institute for Advanced and Continuing Education (NIACE) for the National Research and Development Centre for Adult Literacy and Numeracy (NRDC).

Swan, M. (2007). The impact of task-based professional development on teachers' practices and beliefs: A design research study. Journal of Mathematics Teacher Education, 10(4-6), 217-237. https://doi.org/10.1007/s10857-007-9038-8

Swan, M., Pead, D., Doorman, M., \& Moolddijk. (2013). Designing and using professional development resources for inquiry-based learning. ZDM Mathematics Education, 7, 945-957. https://doi.org/10.1007/s11858-013-0520-8

Wenger, E. (1998). Communities of practice: Learning, meaning and identity. Cambridge: University. https://doi.org/10.1017/CBO9780511803932

Yin, (2013). Case study research. Los Angeles: Sage.

Zaslavsky, O., \& Leikin, R. (2004). Professional development of mathematics teacher educators: Growth through practice. Journal of Mathematics Teacher Education, 7(1), 5-32. https://doi.org/10.1023/B:JMTE.0000009971.13834.e1

\section{Appendix A: Semi-structured interview guide}

\section{Introduction}

What was your most important experience during your participation in the project Primas?

\section{Teaching}

Describe a good lesson and give reasons why you consider the lesson to be good.

Did you implement IBL in your lessons? If so, how?

What challenges did you face with the implementation of IBL?

Primas course leader PD

Why did you decide to become a course leader?

How did you take up your new role as a course leader?

To what extent did you feel prepared to take up this new role?

What challenges did you face when switching between both roles?

How would you rate the quality of the course leader PD?

$P D$ courses of the course leaders

Describe a good PD course and give reasons why you consider the course to be good.

What did you want participants to learn during the course?

How do you plan a PD course? How did you implement it?

What challenges did you face?

To what extent did your participants implement IBL? What challenges did they face?

\section{Appendix B: Coding scheme}

Teaching IBL

Understanding of IBL

Design of a lesson

Reaction of students

Challenges

Development as a teacher

Taking up their new role as a course leader 
Reasons for participation

Needs expressed

Understanding of the role

Challenges faced

Development as a course leader

Feedback to the course leader PD

Relation between theory and practice

Materials

Exchange with colleagues

Preparation to teach IBL

Preparation to be a course leader

Their PD course

Aims of the course

Planning of the course

Design of the course

Feedback of their participants

Implementation of IBL

Challenges participants experienced

Participation rate

\section{Copyrights}

Copyright for this article is retained by the author(s), with first publication rights granted to the journal.

This is an open-access article distributed under the terms and conditions of the Creative Commons Attribution license which permits unrestricted use, distribution, and reproduction in any medium, provided the original work is properly cited. 